that benefit is derived after splenectomy in occasional patients with thalassaemia. The investigations of McFadzean et al. (1958) on Chinese with cryptogenic splenomegaly suggest that this anaemia responds to splenectomy through this mechanism also.

I have tried in this lecture to adopt a physiological approach to the pathological problem of the production of anaemia by the spleen by considering firstly our knowledge of the splenic circulation. I think this approach is

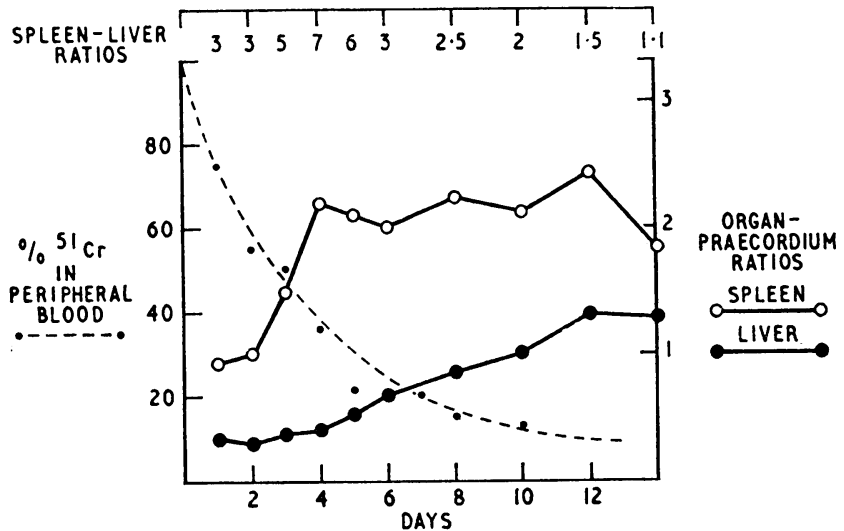

FIG. 11.-Splenic, liver, and blood counts in a man aged 20 with autoimmune haemolytic anaemia whose own red cells were labelled with ${ }^{s 1} \mathrm{Cr}$. Radioactivity in the portal-vein blood at splenectomy indicated that the rise in liver counts after the fourth day was
due to the transfer of ${ }^{51} \mathrm{Cr}$ liberated in the spleen from destroyed red cells.

leading, to a small extent, to an understanding of the mechanisms which may operate and to a clearer understanding of our approach to splenectomy. It is only a beginning, but future progress will come from further investigation of some of the clues which may have already appeared to us. We have advanced some way from the days of Malpighi, when he said of the spleen, "What therefore may be thought of this artificial bowel ? I am perfectly ignorant" (quoted by Stukely, 1722).

In conclusion may I quote again the words of William Stukely, who said: "Certainly if beauty be the first temptation to love we cannot but have a particular affection for the spleen. The delicacy of its construction will at first sight convey a strong desire to know what purpose thereby is aimed at in life."

I am grateful to the British Empire Cancer Campaign for financial support of some of this work.

\section{REFERENCES}

Barcroft, J., and Barcroft, H. (1923). J. Physiol. (Lond.), 58, 138 - Harris, H. A., Orahovats, D., and Weiss, R. (1925). Ibid., 60. 443 .

Björkman, S. E. (1947). Acta med. scand., Suppl. No. 191, 1.

Bowdler, A. J. (1962). Clin. Sci., 23, 181.

- (1963). Ann. intern. Med., 58, 664

Callender, S. T., Powell, E. O., and Witts, L. J. (1945). J. Path. Bact., 57, 129.

Dacie, J. V., Mollison, P. L., Richardson, N., Selwyn, J. G., and Shapiro, L. (1953), Quart. J. Med., 22, 79.

Doan, C. A. (1926). J. exp. Med., 43, 289.

Emmerson, C. P., Shen S. C., Ham, T. H., Flemming, E. M., and Castle, W. B. (1956). Arch. intern. Med., 97, 1

Harris, I. M., McAlister, J. M., and Prankerd, T. A. J. (1957). Clin. Sci., 16, 223 .

- (1958). Brit. J. Haemat., 4, 97.

Henschen, C., and Howald, R. (1929). Arch. klin. Chir., 157, 667

Hodgkin, T. (1822). Edinb. med. surg. J., 70, 83 .

Hughes Jones, N. C., and Szur, L. (1957). Brit. J. Haemat,, 3, 320.

Jacobs, H. S., and Jandl, J. H. (1962). J. clin. Invest., 41, 1514.

Knisely, M. H. (1936). Anat. Rec., 65, 23.

McFadzean A. J. S., Todd, D., and Tsang, K. C. (1958). Blood. 13, 524 .

Mollison, P. L. (1959). Brit. med. J., 2, 1035.

Motulsky, A. G., Casserd, F., Giblett, E. R., Broun, G. O., and Finch, C. A.'(1958). New Engl. J. Med., 259, 1164

Prankerd, T. A. J. (1960). Quart. J. Med., 29, 199 (1961). The Red Cell. Blackwell, Oxford.

Schloesser, L. L., Korst, D. R., Clatanoff, D. V., and Schilling, R. F. (1957). J. clin. Invest., 36, 1470.

Stukely, W. (1722). Goulstonian Lectures, Royal College of Physicians, London.

Young, L. E. (1955). Amer. J. Med., 18, 486.

\title{
STUDIES OF URINARY TRACT INFECTIONS IN INFANCY AND CHILDHOOD
}

\section{ANTIBODY RESPONSE IN DIFFERENT TYPES OF URINARY TRACT INFECTIONS CAUSED BY COLIFORM BACTERIA}

BY

J. WINBERG, M.D.

Department of Paediatrics

\section{H. J. ANDERSEN, M.D. \\ Department of Paediatrics}

K. LINCOLN, M.D.

Department of Clinical Bacteriology

University of Gothenburg, Sweden

\author{
L. A. HANSON, M.D. \\ Department of Bacteriology
}

A urinary tract infection caused by coliform organisms in man may elicit a measurable antibody response as shown as early as 1898 by Pfaundler, who employed a bacterial agglutination technique. Further studies by Siede and Luz (1941) using a similar technique indicated a certain difference in this antibody response in cases with pyelitis and those with cystitis. However, some workers (for example, Gillisen, 1954; Kaarsalo, Kasanen, Laurent, Piiroinen, and Raunio, 1962) have been critical of the possibilities of employing such a technique in the study of human urinary tract infections. Recent studies by Needell, Neter, Staubitz, and Bingham (1955) and by Slifkin, Ward, Fischer, and Cromartie (1959) using a haemagglutination method have given some evidence for the usefulness of such a method in the analysis of the antibody response in this type of coliform infection.
However, the characteristics of this antibody response are incompletely known. It seemed to us, therefore, that it would be interesting to pursue a systematic study of the antibody response, dealing particularly with its specificity and with the possibilities that antibody titration may offer in diagnosis, in following the course of infection, and in the anatomical classification of the site of the infection.

\section{Patients and Controls}

Twenty patients were studied, and there were 25 controls.

Sixteen of the patients had acute infections. They were hospitalized during the initial stage of the disease. Gross anatomical malformations were thought to be ruled out on the following grounds: in most patients by a rapid initial response to treatment and no recurrence during an observation period of at least six months; in those with a bad initial response to 
treatment or a recurrence of infection by normal intravenous urography and urethrocystography.

All patients were treated with "gantrisin" (sulphafurazole) in a dose of $200 \mathrm{mg}$. per $\mathrm{kg}$. of body weight per 24 hours for 10 days. Some were treated with a reduced dose for the following two to three months. Treatment was instituted as soon as the diagnosis was established, as a rule within a few days of the onset of clinical symptoms.

Four of the patients had chronic bacteriuria, and the clinical details are given in the Table (see also Fig. 6).

Clinical Detalls in Four Patients with Chronic Bacteriuria

\begin{tabular}{|c|c|c|c|c|c|c|}
\hline Patient & Symptoms & $\begin{array}{c}\text { Last } \\
\text { Febrile } \\
\text { Reaction } \\
\text { (years } \\
\text { ago) }\end{array}$ & $\begin{array}{c}\text { Concen- } \\
\text { tration } \\
\text { Capacity } \\
(\text { mOsm l. })\end{array}$ & $\begin{array}{c}\text { i.v. } \\
\text { Urography }\end{array}$ & $\begin{array}{c}\text { Bac- } \\
\text { teriuria } \\
\text { and } \\
\text { Leuco- } \\
\text { cyturia }\end{array}$ & $\begin{array}{c}\text { Duration } \\
\text { of } \\
\text { Therapy } \\
\text { (months) }\end{array}$ \\
\hline $\mathbf{A}$ & $\begin{array}{l}\text { Burning } \\
\text { frequency } \\
\text { several } \\
\text { years }\end{array}$ & Several & 1,190 & Normal & $\begin{array}{l}\text { Established } \\
\text { six times } \\
\text { last year }\end{array}$ & $\begin{array}{l}\text { 12; unsuc- } \\
\text { cessful } \\
\text { with- } \\
\text { drawal }\end{array}$ \\
\hline B & $\begin{array}{l}\text { Slight back } \\
\text { pains, } \\
\text { burning } \\
\text { frequency. } \\
\text { Right } \\
\text { nephrec- } \\
\text { tomy }\end{array}$ & $>3$ & $\begin{array}{c}819 \\
\text { (low) }\end{array}$ & $\begin{array}{l}\text { Reduced } \\
\text { paren- } \\
\text { chyma } \\
\text { right. } \\
\text { Left } \\
\text { normal }\end{array}$ & $\begin{array}{c}\text { Continuous } \\
3 \text { years }\end{array}$ & $\begin{array}{c}24 \text {; con- } \\
\text { tinuous }\end{array}$ \\
\hline C & $\begin{array}{l}\text { Slight back } \\
\text { pains, } \\
\text { burning } \\
\text { frequency } \\
\text { many years }\end{array}$ & 10 & $\begin{array}{c}780 \\
\text { (low) }\end{array}$ & $\begin{array}{c}\text { Calices } \\
\text { coarse }\end{array}$ & $\begin{array}{l}\text { Appears } \\
\text { soon after } \\
\text { with- } \\
\text { drawal of } \\
\text { therapy }\end{array}$ & $\begin{array}{l}24 \text {; unsuc- } \\
\text { cessful } \\
\text { with- } \\
\text { drawal }\end{array}$ \\
\hline D & $\begin{array}{l}1948-59 \\
\text { "innumer- } \\
\text { able" acute } \\
\text { infections } \\
1960-2 \\
\text { slight back } \\
\text { pains, right } \\
\text { side }\end{array}$ & $>2$ & 1,035 & $\begin{array}{l}\text { Paren- } \\
\text { chymal } \\
\text { reduction } \\
\text { right } \\
\text { lower } \\
\text { pole }\end{array}$ & $\begin{array}{l}\text { Appears } \\
\text { soon after } \\
\text { with- } \\
\text { drawal of } \\
\text { therapy }\end{array}$ & $\begin{array}{l}30 ; \text { unsuc- } \\
\text { cessful } \\
\text { with- } \\
\text { drawal }\end{array}$ \\
\hline
\end{tabular}
All symptoms of intermittent character. Sedimentat on rate, W.B.C., haemo

The controls were 25 infants and children, aged from 5 days to 15 years, who were in hospital because of feeding problems or psychosomatic symptoms. None of them had a history of urinary tract infections or any pathological constituents of the urine.

\section{Methods}

The diagnosis of urinary tract infection and classification with regard to the anatomical site of infection was based on the following criteria:

(1) A bacterial count of 100,000 micro-organisms or more per ml. of urine.

(2) A white-cell count in the uncentrifuged, fresh urine of 25 or more per c.mm. in the male, and 50 or more in the female.

(3) If the urinary concentration capacity was reduced during the acute stage of the disease the patient was classified as having pyelonephritis (Winberg, 1959a). If the capacity was normal the infection was probably located distal to the renal parenchyma, and the patient was classified as having cystitis and/or pyelitis.

Urinary culture was performed on immediately cooled, cleanvoided specimens. Serial tenfold dilutions were spread on the surface of three different solid media, permitting a preliminary bacteriological diagnosis and a quantitative estimation of the number of bacteria of each species. In the routine work a simplified biochemical differentiation of the Enterobacteriaceae family was adopted. The term coliform bacteria, or coliforms, was used, first, for all rapid lactose-fermenting enteric Gram-negative rods; secondly, for all lactose non-fermenters not belonging to Shigella, Salmonella, Arizona, and Proteus. Coliform bacteria in this paper thus include Escherichia coli. Citrobacter, Klebsiella, and Cloaca (Aerobacter). Typing of the $E$. coli strains isolated from the patients with infections was performed by Drs. Frits and Ida Örskov, of the Statens Seruminstitut, Copenhagen, Denmark. These studies will be published later.
Urinary white cells were counted in the voided fresh, uncentrifuged urine in a Fuchs-Rosenthal counting chamber, as described by Stansfeld and Webb (1953), Linneweh (1957), and others.

The renal concentration capacity was estimated according to Winberg (1959b).

The antigen preparations employed in the investigations of the antibody response in patients with urinary tract infections were obtained from the strains isolated from the urine of the patients. The serum of each patient was tested against the strain isolated from the same patient. The bacteria were harvested and suspended in saline. The bacterial concentration was adjusted to $300-1,200$ millions per ml. by means of comparison with a McFarlane scale. The suspensions were boiled for two hours and centrifuged for 30 minutes at 3,000 r.p.m. The supernatant was used as antigen in the experiments.

The study of the control material was performed with bacterial strains cultured from the children's stools.

The method employed for the haemagglutination technique was based on the reports of Needell et al. (1955) and Neter, Bertram, Zak, Murdock, and Arbesman (1952). Sheep redblood cells washed three times in saline were used as carriers of the bacterial antigens. Washed and packed blood celis $(0.1 \mathrm{ml}$.) were incubated together with a $5.0 \mathrm{ml}$. antigen suspension prepared from the bacterial strain, isolated from the urine of the patient to be tested, or, in the control material, from strains isolated from the stools. After 30 minutes at $37^{\circ} \mathrm{C}$. the red-blood cells were washed three times in physiological saline and then diluted to a concentration of $1 \%$. Of this suspension, $0.1 \mathrm{ml}$. was added to the same amount of twofold serial dilutions of the serum from the patient being tested. The serum had previously been inactivated at $56^{\circ} \mathrm{C}$. for 30 minutes and absorbed with uncoated sheep red-blood cells. The haemagglutination reactions obtained were recorded after incubation for three hours at $37^{\circ} \mathrm{C}$. Two parallel determinations were always performed on each serum sample. The controls were uncoated sheep red-blood cells in undiluted serum and coated sheep red-blood cells in saline.

\section{Results}

Analysis of sera from the 25 infants and children in the control group in no case showed titres of coli antibodies against their homologous faecal coli strains higher than 1:64 (Fig. 1). The sample is too small to say anything definite about the correlation of titres with the age of the children.

Acute Pyelonephritis, Age 0 to 2 Months (Two Patients).-As shown in Fig. 2 the antibody response may fail to appear in this age group.

Acute Pyelonephritis, Age 2 to 12 Months (Six Patients).-In this category the coli antibody titres rose considerably (Fig. 3 ). In two of the patients the rise was demonstrable within a week

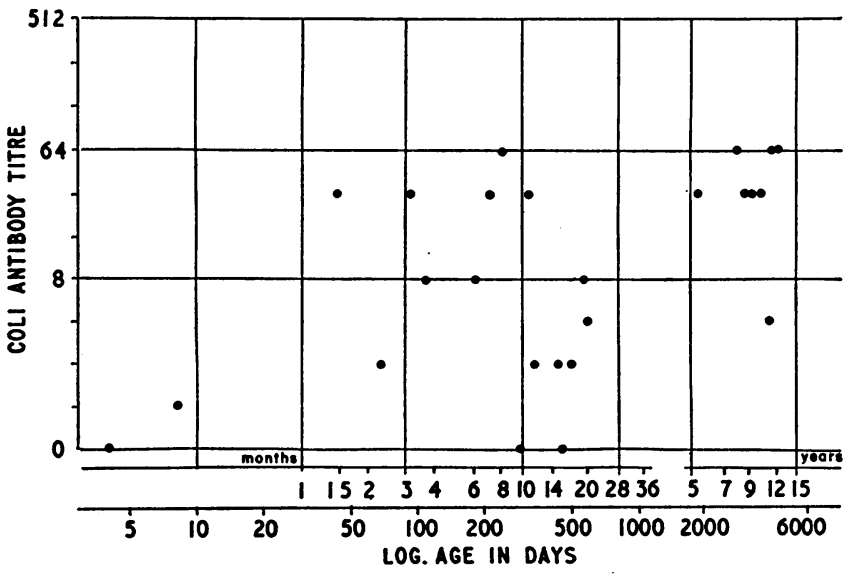

Fra. 1.-Coli antibody titres in the sera from control group of 25 infants and children without urinary tract infections. Antigen derived from homologous faecal strains. 
of onset of clinical signs of infection. There was a relatively rapid decrease of the titres towards the level of the control titres. In patients with no bacterial recurrence the titres remained at this level. In two patients there was a suspected relapse with bacteriuria three months after the original infection. In these two patients there were 50,000 bacteria

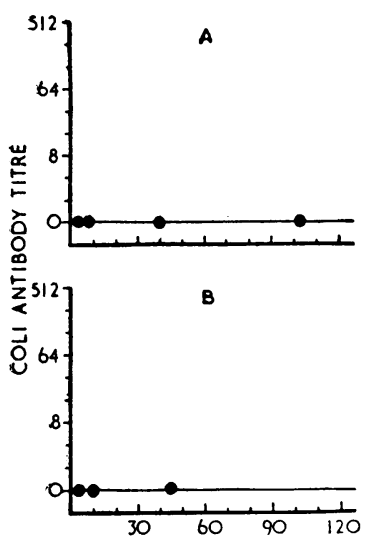

DAYS AFTER ONSET OF SYMPTOMS

FIG. 2.-Coli antibody titres in sera from two patients with acute pyelonephritis aged 6 and 5 weeks respectively at onset of symptoms of infection. Reduced concentration capacity. Antigen derived from homologous urinary coli strain at onset of symptoms. per ml. urine but no leucocyturia ( 9 and 14 white cells respectively per c.mm. uncentrifuged urine) and no concomitant clinical symptoms. In these two patients only, there was a second, though small, rise in the antibody titre (Fig. 3, E and F) when blood serum obtained at relapse was tested against the bacteria isolated at the original infection. Bacteria isolated at relapse were not tested against the homologous serum.

Acute Pyelonephritis, Age More than 12 Months (Four Patients).-The antibody response in these patients was of the same general type as in those 2 to 12 months of age (Fig. 4). A wide distribution of the highest titres recorded was observed in the various patients. In one patient (Fig. 4, B) there was a slow fall of the antibody titre, though there were no signs or symptoms of relapse. In this patient serum was tested not only against the urinary strain but also against the faecal ones. A similar antibody increase was demonstrable with both antigen preparations.

Cystitis and/or Pyelitis, Age More than 12 Months (Four Patients). - The titres demonstrable in sera from these patients were all found to be of the same magnitude as those of the controls. In some cases a small increase of antibody titres was observed during the course of infection. However, the significance of this increase in titre is uncertain (Fig. 5).

Chronic Bacteriuria, Age More than 12 Months (Four Patients).-These were patients with persisting bacteriuria and intermittent burning, frequency, and slight back pains for several years, but who had had no recent attacks of fever. (See Table.) Moderately increased levels of antibodies were observed in these patients when tested against various bacterial strains, isolated from their urine on different occasions (Fig. 6).

\section{Discussion}

Two of the main problems met with in the clinical evaluation of suspected urinary tract infections are: is there in fact an infection present; if so, is the infection located in the renal parenchyma or in the lower part of the urinary tract? As seen in Figs. 3 to 5 there seems to be a definite difference between the antibody response in patients with acute pyelonephritis (reduced renal con- centration capacity) and with infection distal to the renal parenchyma (cystitis, pyelitis; normal concentration capacity). These results indicate that it may be possible to differentiate between the two types of infection by means of the coli antibody response. Such a possibility would be of special value in patients with chronic bacteriuria and

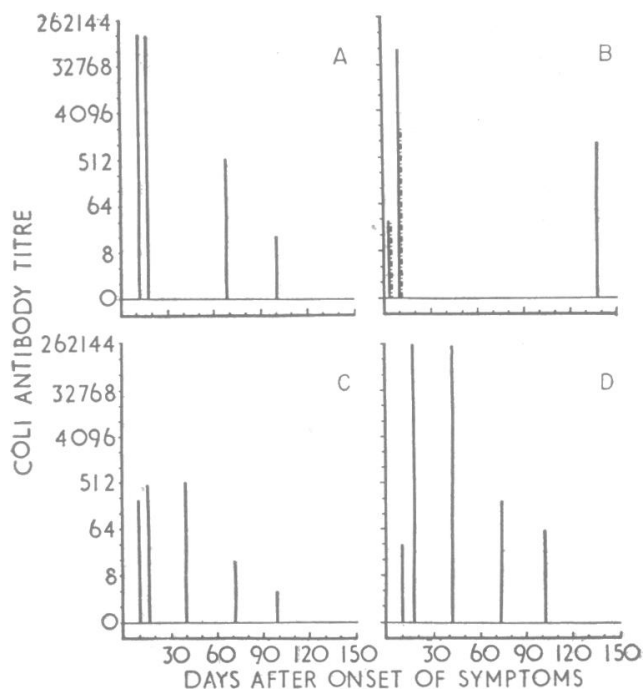

Fig. 4.-Coli antibody titres in sera from four children with acute pyelonephritis, aged $>12$ months with reduced concentration capacity. No relapse. Continuous line =antigen derived from homologous urinary coli strains isolated at onset of symptoms. Broken line $=$ antigen derived from homologous faecal coli strains.

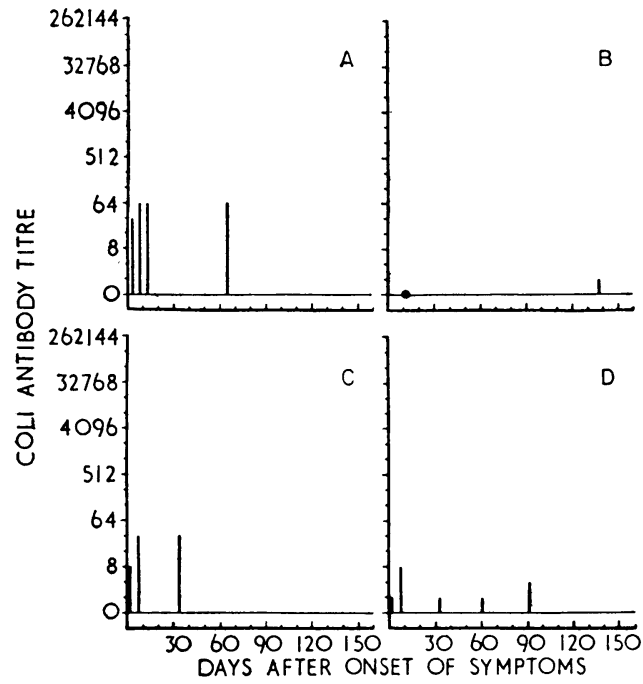

FIG. 5.-Coli antibody titres in sera from four children with acute lower urinary tract infections, aged $>12$ months, with normal concentration capacity. Antigen derived from homologous urinary coli strain isolated at onset of symptoms.
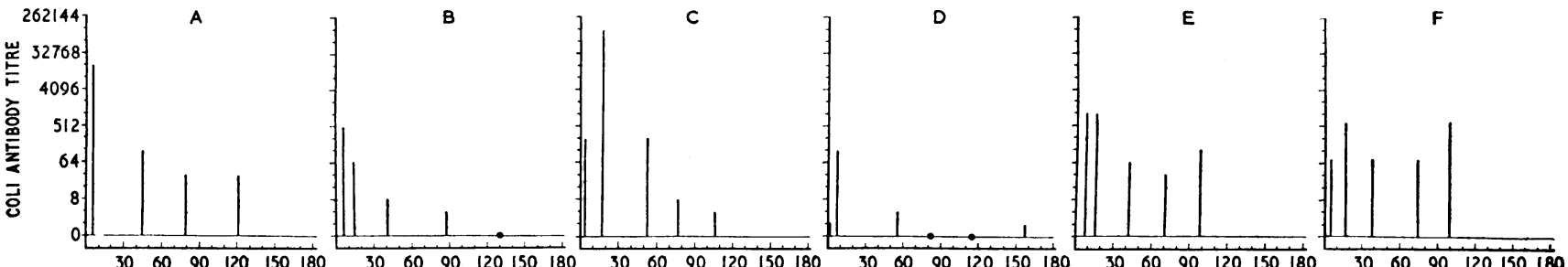
DAYS AFTER ONSET OF SYMPTOMS

FIG. 3.-Coli antibody titres in sera from six infants with acute pyelonephritis, aged 2 to 12 months, with reduced concentration capacity. Bacteriological relapse without clinical symptoms in patients $\mathbf{E}$ and $\mathrm{F}$ about three months after onset of clinical signs of infection. Antigen derived from homologous urinary coli strain isolated at onset of symptoms. 
asymptomatic bacteriuria following acute infections, where the concentration capacity test is of lesser value than in acute infections. Further systematic studies are, however, necessary before any definite conclusions can be drawn.
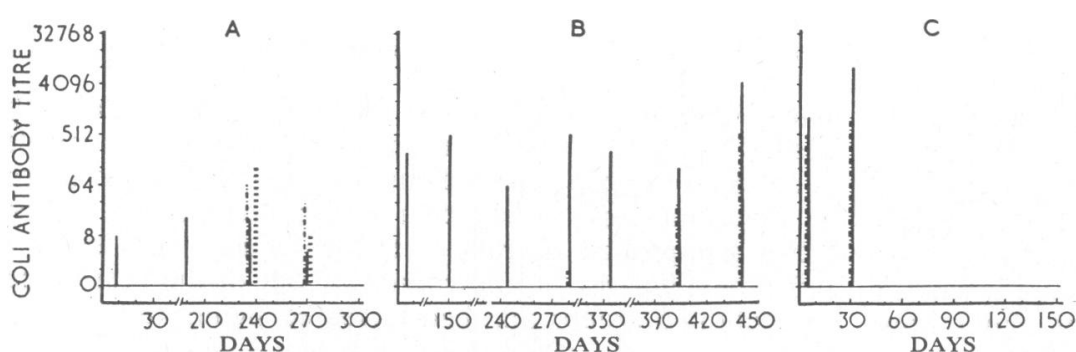
by the haemagglutination technique, often shows much less tendency to terminate spontaneously than acute uncomplicated pyelonephritis, which elicits a rapid and marked antibody response. The

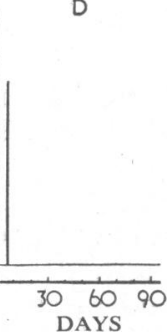

Fig. 6.-Coli antibody titres in sera from four children, aged $>12$ months, with indolent chronic bacteriuria and normal or low normal concentration capacity (see Table). Continuous line $=$ antigen derived from homologous urinary coli strain isolated at onset of symptoms. Broken lines $=$ antigens derived from homologous urinary coli strains isolated at later investigations.

same as for cystitis holds true also for neonatal urinary tract infections (Lincoln and Winberg, unpublished results).

From the work of Neter, Bertram, Zak, Murdock, and Arbesman (1952) it seems probable that a specific reaction is obtained between the bacterial antigens and corresponding serum antibodies with the method

The close correlation that may be observed between the titres and the clinical course is illustrated by a small but possibly significant rise of titres in two cases with suspected bacteriological recurrence $(50,000$ coli bacteria per ml. of urine) after an acute infection (Fig. 3, E, F). The raised titres in these patients may point to a parenchymal process, though the patients had no clinical symptoms. The raised titres in the patients with chronic bacteriuria (Fig. 6) may likewise point to a parenchymal process.

Since the patients who relapsed after acute infections had no clinical symptoms at the time of investigation the findings illustrated in Fig. 3, E and F, may indicate the possibility of using the technique as a diagnostic tool in cases where urinary tract infection is suspected but not certain. With faecal strains as a source of antigen the antibodies may also be demonstrated (Fig. 4, B); this finding may likewise be used diagnostically, especially in those patients whose urine reveals nothing abnormal, a situation common in obstructive diseases of the urinary tract, and when bacterial growth is inhibited by treatment started before urine has been saved for culture.

The rapid rise of coli antibody titres in most cases of acute pyelonephritis is expected; the rapid fall, however, is noteworthy. It is not known whether the course of the antibody titres is modified by the influence of effective treatment. The observed variability of the peak titres may be due to several factors needing further systematic study.

The role of the specific coli antibodies in the pathogenesis and course of the infection is of great interest. In patients below the age of 2 months the antibody titre may not be demonstrable (Fig. 2). This may be in accordance with the limited capacity to form antibodies in this early period of life (Vahlquist, Murray, and Persson, 1948; Good and Zak, 1956). This limited capacity could be one of the major reasons for the well-known susceptibility to coli infections in this age group, and the high frequency of urinary tract infections during the first few months of life (Stansfeld, 1954). The relatively frequent occurrence of asymptomatic relapse-often with only a slight inflammatory reaction in the urine-is also of interest in this connexion. It may be that the original infection has caused an acquired immunity that limits the growth of antigenically related strains causing the relapse in these cases. Consequently one would then suppose a relapse with acute symptoms to be caused by antigenically unrelated strains. Recent observations in rats by Sanford, Hunter, and Souda (1962) would support such a hypothesis. Work is going on to elucidate the problem from the clinical point of view. In this connexion it is also of interest to note that cystitis, employed in their study and in this study. By means of haemagglutination-inhibition experiments with antigens from a large number of various coli strains we have found further evidence for such a specificity (Andersen, Hanson, Lincoln, and Winberg, unpublished results). These studies also indicate various degrees of antigenic relationships between these strains. In some cases no such relationship was demonstrable with the antigen preparations used.

\section{Summary}

A report is given of the coli antibody response in infants and children with acute and chronic urinary tract infections. The coli antibody titre in serum of controls was also determined. A haemagglutination technique was employed.

In acute infections with lowered concentration capacity (pyelonephritis) there was a marked and rapid antibody response (except in patients below the age of 2 months), whereas in acute infections with normal concentration capacity (cystitis and/or pyelitis) there was no definite change in the antibody titre. This might permit differentiation between infections with and without involvement of the renal parenchyma. In patients with chronic, indolent bacteriuria and pyuria the titres were raised. This might suggest a parenchymal process in these cases. A close correlation between clinical course and the titre is demonstrated in several cases.

\section{REFERENCES}

Gillisen, G. (1954). Medizinische, 1, 778

Good, R. A., and Zak, S. J. (1956). Pediatrics, 18, 109.

Kaarsalo, E., Kasanen, A., Laurent, B., Piiroinen, O., and Raunio, V. (1962). Ann. Med. intern. Fenn., 51, 31.

Linneweh, F. (1957). Dtsch. med. Wschr., 82, 438.

Needell, M. H., Neter, E., Staubitz, W. J., and Bingham, W. A. (1955). J. Úrol., 74, 674.

Neter, E., Bertram, L. F., Zak, D. A., Murdock, M. R., and Neter, E., Bertram, L. F., Zak, D. A., Murdock Pfaundler, M. (1898). Zbl. Bakt., 23, 9, 71, 131.
Sanford, J. P., Hunter, B. W., and Souda, L. L. (1962). J. exp. Med., 115, 383.

Siede, W., and Luz, K. (1941). Klin. Wschr., 20, 241.

Slifkin, M̈., Ward, L. M., Fischer, J. J., and Cromartie, W. J. (1959)." Bact. Proc., 98.

. Proc. roy. Soc. Med., 47, 631

- and Webb, J. K. G. (1953). Arch. Dis. Childh., 28, 386

Vahlquist, B., Murray, U., and Persson, N. G. (1948). Acta paediat. (Uppsala), 35, 130

Winberg, J. (1959a). Ibid., 48,577

(1959b). Ibid., 48, 318

Hypertension and Coronary Artery Disease, the proceedings of a symposium held in Chelmsford in 1961 under the auspices of the Chelmsford Medical Society and the Mid-Essex Branch of the B.M.A., has been published by Pitman Medical Publishing Co. Ltd., 46 Charlotte Street, London W.1. 